\title{
Inhibitory Effect of Soil Micropores and Small Mesopores on Phosphate Extraction From Soils
}

\section{AUTHOR(S):}

Watanabe, Tetsuhiro; Hase, Emiko; Funakawa, Shinya; Kosaki, Takashi

\section{CITATION:}

Watanabe, Tetsuhiro ...[et al]. Inhibitory Effect of Soil Micropores and Small Mesopores on Phosphate Extraction From Soils. Soil Science 2015, 180(3): 97-106

\section{ISSUE DATE:}

2015-03

URL:

http://hdl.handle.net/2433/203655

\section{RIGHT:}

(c) 2015 Wolters Kluwer Health. This is a non-final version of an article published in final form in [Soil Science. 180(3):97106]:; The full-text file will be made open to the public on 1 March 2016 in accordance with publisher's 'Terms and

Conditions for Self-Archiving'.; This is not the published version. Please cite only the published version.; この論文は出版 社版でありません。引用の際には出版社版をご確認ご利用ください。 
Inhibitory effect of soil micro- and small meso-pores on phosphate extraction from soils

Tetsuhiro Watanabe ${ }^{1,2}$ (Ph.D.), Emiko Hase ${ }^{1}$ (Ph.D.), Shinya Funakawa ${ }^{1,2}$ (Ph.D.), Takashi Kosaki ${ }^{3}$ (Ph.D.)

${ }^{1}$ Graduate School of Agriculture, Kyoto University, Kyoto 606-8502, Japan

${ }^{2}$ Graduate School of Global Environmental Studies, Kyoto University, Kyoto 606-8501, Japan

${ }^{3}$ Graduate School of Urban Environmental Sciences, Tokyo Metropolitan University, Tokyo 192-0397, Japan

Address for correspondence: Dr. Tetsuhiro Watanabe, Graduate School of Agriculture, Kyoto University, Kitashirakawa-oiwake-cho, Sakyo, Kyoto 606-8502, Japan.

Tel.: +81-75-753-6101; fax: +81-75-753-6103.

E-mail address: nabe14@kais.kyoto-u.ac.jp

Running title: Soil micro-pores reduce phosphate extractability

Sources of support: JSPS KAKENHI Grant Numbers 24228007, 26660048 
ABSTRACT: Slow release of added phosphate in soils is of fundamental importance for plant nutrition and pollution in aqueous environments. The diffusion of phosphate in micro- and meso-pores after desorption from the inside surface of pores is the most likely mechanism for the slow release. There are limited experimental data on the effects of micro- and meso-pores and differences in the effects of these pores among various soil types have not been reported. Phosphate extractability was characterized using Hedley's fractionation method and sequential anion exchange membrane extraction for soils with widely different acid oxalate-extractable $\mathrm{Al}$ and $\mathrm{Fe}\left(\mathrm{Al}_{\mathrm{o}}\right.$ and $\mathrm{Fe}_{\mathrm{o}}$ ) contents $\left(1.7-87 \mathrm{~g} \mathrm{~kg}^{-1}\right.$ of $\left.\mathrm{Al}_{\mathrm{o}}+1 / 2 \mathrm{Fe}_{\mathrm{o}}\right)$. We measured the total specific surface area (SSA), the SSA of micro- and meso-pores, and the decrease in SSAs after phosphate sorption. The proportion of labile phosphate relative to added phosphate and the rate of phosphate release in sequential extractions were negatively correlated with $\mathrm{Al}_{\mathrm{o}}$ and $\mathrm{Fe}_{\mathrm{o}}$ and the porosity of the soils (the $0.7-4-\mathrm{nm}$ pore SSA relative to the total SSA). The soil samples in which the 0.7-4-nm pore SSA decreased with added phosphate showed low proportions of labile phosphate and slow release rates. We demonstrated that phosphate release from soils with high $\mathrm{Al}_{\mathrm{o}}$ and $\mathrm{Fe}_{\mathrm{o}}$ contents was more difficult because of phosphate sorption into micro- and small meso-pores. Availability of fertilizer phosphate might be low in soils with high porosity, but the effects of aging and competition with organic molecules should be further investigated.

Keywords: phosphorus; acid oxalate-extractable aluminum and iron; specific surface area; micropore; anion exchange resin

\section{INTRODUCTION}

The release of added phosphate from soils is important for both agriculture and the environment because the availability of added phosphate affects agricultural production and phosphate leaching causes eutrophication of water bodies. Better understanding of the characteristics of phosphate release and controlling factors is needed to ensure good crop health, reduce uneconomical applications and minimize environmental loads.

The effects of soil components on phosphate release, especially the effects of $\mathrm{Al}$ and $\mathrm{Fe}$ oxides/hydroxides, have been suggested from the results of many studies (e.g., Sharpley, 1983; Freese et al., 1992; Colombo et al., 1994; Hartono et al., 2006). Freese et al. (1992) suggested the importance of active $\mathrm{Al}$ and Fe to phosphate extraction from soils, based on their observation that high active $\mathrm{Al}$ and Fe contents impaired phosphate extractability. Hartono et al. (2006) found different added phosphate recovery rates from 15 soils from Indonesia and suggested that the abundance of oxide surfaces affected the recovery rate. One of the proposed mechanisms of the control of phosphate release or extractability from oxides includes diffusion in soil pores (Parfitt, 1978; Arai and Sparks, 2007). 
Phosphate sorption and release processes show hysteresis, i.e., sorbed phosphate is released slowly (Arai and Sparks, 2007). Clarification of the reason for this slow release will increase our understanding of phosphate behavior in soils. Phosphate sorption processes in soils include fast ligand exchange reactions onto surface sites of Fe and Al oxides/hydroxides, and subsequent slow reactions that deposit phosphate within soil particles (Parfitt, 1978; Addiscott and Thomas, 2000; McGechan and Lewis, 2002). Generally, less phosphate is released than the amount added because of deposition of phosphate within soil particles (McGechan and Lewis, 2002) in addition to inner-sphere complexation caused by ligand exchange reactions. The slow reactions include the physical process of diffusion into micro- and meso-pores (intra- and inter-particle) and the subsequent chemical process of adsorption onto the inside surface of the pores (Arai and Sparks, 2007), which we will refer to as sorption into micro- and meso-pores. Micro- and meso-pores are defined as pores of $<2 \mathrm{~nm}$ and 2-50 nm, respectively (Everett, 1972). Diffusion into micro- and meso-pores involves ion penetration into individual particle fissures and between aggregates (Arai and Sparks, 2007). Given the chemical reaction of phosphate with $\mathrm{Al}$ and Fe oxides/hydroxides, it might be more appropriate to think of the process as the movement of a reaction front (Addiscott and Thomas, 2000). Phosphate trapped in micro- and meso-pores is difficult to extract because after desorption of phosphate from surface sites in micro- and meso-pores it then has to diffuse into bulk solution before extraction or release from soil particles.

Very few studies have reported on adsorbent porosity or the effects of microand meso-pores on phosphate sorption and extraction from soils (Torrent et al., 1992), although soil pore structure is likely to affect phosphate extraction. Inhibitory effects on phosphate extraction by micro- and meso-pores have been reported for synthetic materials (such as lepidocrocite (Cabrera et al., 1981), goethite (Strauss et al., 1997), hematite (Colombo et al., 1994) and amorphous Al- and Fe-hydroxide-based water treatment residues (Makris et al., 2004)) and a few natural materials (such as goethite-rich soils, ferricrete and lake ore (Torrent et al., 1992)). The effects of these pores on phosphate extractability have not been tested for various soil types. Clarifying the characteristics of phosphate release in soils with different porosity would be useful to predict phosphate availability to plants and risk of phosphate leaching after fertilization.

Phosphate extractability and the effects of soil porosity and sorption into micro- and meso-pores might differ between soil types. To investigate surface effects on phosphate extractability for soils with a wide range of sorption capacities, adding an amount of phosphate equivalent to the sorption capacity provides equal phosphate loading conditions. According to Barros et al. (2005), extraction of phosphate from soils is related to the amount of phosphate added, i.e., a lower rate of phosphate addition results in a lower rate of extraction of the added and sorbed phosphate. 
There are various methods for phosphate extraction. Hedley's fractionation method (Tiessen and Moir, 2008) is one of the most frequently applied soil phosphorus fractionation methods. This fractionation method is an attempt to separate phosphorus pools according to their lability (Tiessen and Moir, 2008) and has been widely applied for detailed investigation of dynamics and bioavailability of phosphorus in soils (Negassa and Leinweber, 2009; Condron and Newman, 2011). Another method uses sequential extractions on anion exchange membranes (AEM). Extraction using AEM has been successfully performed in phosphorus desorption studies (Fernandes and Coutinho, 1997; Roboredo and Coutinho, 2006) and has been proven useful in determining plant-available phosphorus (Nuernberg et al., 1998).

The objectives of this study were to examine the effect of micro- and meso-pores and phosphate sorption into these pores on phosphate extractability and to investigate differences in the effect among various soil types. We characterized phosphate extractability using Hedley's fractionation method and sequential AEM extractions and quantified the specific surface area (SSA) of the soil micro- and meso-pores before and after adding an amount of phosphate equivalent to the sorption capacity of each soil. We hypothesized that porosity is different among soils and that the porosity and sorption of phosphate into micro- and meso-pores would reduce the rate of phosphate release from soils and the proportion of labile phosphate.

\section{MATERIALS AND METHODS}

\section{Soil Samples}

To evaluate the effects of porosity and phosphate sorption into micro- and meso-pores on the extractability of phosphate from various soil types, we used soils with a wide range of acid oxalate-extractable $\mathrm{Al}$ and $\mathrm{Fe}\left(\mathrm{Al}_{\mathrm{o}}\right.$ and $\left.\mathrm{Fe}_{\mathrm{o}}\right)$ contents, which are considered to be related to soil porosity. The values of $\mathrm{Al}_{\mathrm{o}}$ were $0.88-74 \mathrm{~g} \mathrm{~kg}^{-1}$ and $\mathrm{Fe}_{\mathrm{o}}$ were $0.79-26 \mathrm{~g} \mathrm{~kg}^{-1}$; the values for $\mathrm{Al}_{\mathrm{o}}+1 / 2 \mathrm{Fe}_{\mathrm{o}}$, based on the criteria for Andisols (Soil Survey Staff, 1999), were $1.7-87 \mathrm{~g} \mathrm{~kg}^{-1}$. Thirty sub-surface soils from different regions in Asia, specifically Thailand, Indonesia and Japan, were used in this study (Table 1).

The soils from Thailand and Indonesia developed under tropical climatic conditions and were mostly classified as Ultisols and Alfisols with high kaolinite contents. The soils from Japan developed under temperate climatic conditions and were mostly classified as Inceptisols with relatively high hydroxyl-interlayered vermiculite contents. Four soils from Japan that developed on volcanic ash were also used, and they contained large amounts of short-range-ordered minerals, judging from the high acid oxalate-extractable Si levels (Shang and Zelazny, 2008) (Table 1).

To clarify the effects of soil mineralogy on phosphate sorption and subsequent extraction, we chose samples that had relatively low total carbon contents $(2.8-18 \mathrm{~g}$ $\mathrm{kg}^{-1}$ ) so that the variation in phosphate sorption-desorption characteristics because of 
carbon content was low. Clay contents of the samples were $20-50 \%$. The soils were air-dried, ground and passed through a 2-mm sieve before analysis.

\section{Determination of General Properties of Soil Samples}

The $\mathrm{pH}$ was measured, after mixing the soil with deionized water at a ratio of 1:5 (soil weight, g, to water volume, $\mathrm{mL}$ ), using a glass electrode (Blakemore et al., 1987). The total carbon content in each soil was measured using an NC analyzer (SUMIGRAPH NC-800, Sumika Chemical Analytical Service, Osaka, Japan). The clay content was determined using the pipette method (Gee and Or, 2002). The volcanic soils were not dispersible, so Jeffries acid oxalate treatment (Jeffries, 1946; Wada and Kawano, 1978) was applied before the soils were dispersed for the clay content determination. Oxalate-extractable $\mathrm{Fe}, \mathrm{Al}$ and $\mathrm{Si}\left(\mathrm{Fe}_{\mathrm{o}}, \mathrm{Al}_{\mathrm{o}}\right.$ and $\left.\mathrm{Si}_{\mathrm{o}}\right)$ were extracted with $0.2 \mathrm{~mol} \mathrm{~L}^{-1}$ ammonium oxalate at $\mathrm{pH} 3$ in a dark room (Blakemore et al., 1981) and measured with an inductively coupled plasma atomic emission spectrometer (ICP-AES, SPS1500VR, Seiko Instruments Inc., Chiba, Japan). The dithionite-citrate-bicarbonate extractable $\mathrm{Fe}\left(\mathrm{Fe}_{\mathrm{d}}\right)$ was extracted following the method published by Mehra and Jackson (1960) and measured using ICP-AES. Total phosphorus in the original soils was determined after digestion with perchloric acid, and measured using the ascorbic acid-molybdenum blue method published by Murphy and Riley (1962). Absorbance at $710 \mathrm{~nm}$ was determined using a UV-VIS spectrophotometer (UV-1200, Shimadzu, Kyoto, Japan).

\section{Preparation of Phosphate-sorbed Samples Based on Predetermined Phosphate Maximum Sorption Capacity}

The maximum phosphate sorption capacity was determined from the Langmuir sorption isotherm, which is commonly used to determine phosphate sorption capacity (McGechan and Lewis, 2002). Extraction experiments could then be performed with every soil sample having equal phosphate loading conditions. Five different phosphate concentrations, the range of which was different for different soils, were used for isotherm determination. Phosphate sorption isotherms were obtained by mixing $0.500 \mathrm{~g}$ aliquots of soil with five $40-\mathrm{mL}$ aliquots of $0.01 \mathrm{~mol} \mathrm{~L}^{-1} \mathrm{CaCl}_{2}$ solution containing different concentrations of $\mathrm{KH}_{2} \mathrm{PO}_{4}$ in 50 - $\mathrm{mL}$ polyethylene centrifuge tubes on a shaker at $120 \mathrm{rpm}$ for $24 \mathrm{~h}$ at $25^{\circ} \mathrm{C}$. The amount of phosphate in the supernatant solution was determined using the method published by Murphy and Riley (1962) after centrifugation at 2,000 $\mathrm{rpm}$ for $10 \mathrm{~min}$ and filtration (filter paper No. 6, Advantec, Tokyo, Japan). The amount of phosphate sorbed by the soils was calculated as the difference between the amount of phosphate added and the amount remaining in solution. The experiments were conducted at the unmodified soil $\mathrm{pH}$ values. The data obtained were fitted to the Langmuir equation and the maximum phosphate sorption capacity was calculated using SigmaPlot 11.0 software (Systat Software Inc., San Jose, CA, USA). 
To prepare soils for extraction experiments, 0.500 -g samples of each soil were incubated in centrifuge tubes for $24 \mathrm{~h}$ at $25{ }^{\circ} \mathrm{C}$ and $60 \%$ gravimetric moisture content (weight/weight), after adding an amount of phosphate equal to the maximum sorption capacity as a $\mathrm{KH}_{2} \mathrm{PO}_{4}$ solution. Control samples, which were soil samples to which water (without phosphate) was added, were prepared and tested in the same way as the phosphate-treated samples.

\section{Phosphate Extraction Using Hedley's Sequential Fractionation Method}

Phosphate extractability was determined using a modified Hedley's fractionation method (Hedley et al., 1982; Tiessen and Moir, 2008) after adding an amount of phosphate equal to the maximum phosphate sorption capacity and incubating for $24 \mathrm{~h}$. Briefly, soil-sorbed phosphate was first extracted with an anion exchange membrane and then residual phosphate was obtained by a stepwise series of extractions using weak alkaline, strong alkaline with and without sonication, and strong acid. This method was suitable for all types of soils, including volcanic soils (Redel et al., 2007).

Soil phosphorus was sequentially fractionated into six components: phosphate removed by an anion exchange membrane (AEM, BDH No. 55164, VWR International Ltd., Lutterworth, UK) (Resin-P); phosphate extracted with 0.5 mol $\mathrm{L}^{-1}$ sodium bicarbonate solution $\left(\mathrm{NaHCO}_{3}-\mathrm{P}\right)$; phosphate extracted with $0.1 \mathrm{~mol} \mathrm{~L}^{-1}$ sodium hydroxide solution without sonication $(\mathrm{NaOH}-\mathrm{P})$; phosphate extracted with $0.1 \mathrm{~mol} \mathrm{~L}^{-1}$ sodium hydroxide solution with sonication (Sonicate/ $\mathrm{NaOH}-\mathrm{P}$ ); phosphate extracted with $1 \mathrm{~mol} \mathrm{\textrm {L } ^ { - 1 }}$ hydrochloric acid solution (HCl-P); and residual phosphorus (Residual-P). The Residual-P content was determined by subtracting the sum of Resin-P, $\mathrm{NaHCO}_{3}-\mathrm{P}, \mathrm{NaOH}-\mathrm{P}$, Sonicate/NaOH-P, and $\mathrm{HCl}-\mathrm{P}$ from the total phosphorus content, which was the sum of the added phosphate and the original soil phosphorus content. For $\mathrm{NaHCO}_{3}-\mathrm{P}, \mathrm{NaOH}-\mathrm{P}$ and Sonicate/NaOH-P, inorganic and organic phosphate $\left(\mathrm{P}_{\mathrm{i}}\right.$ and $\mathrm{P}_{\mathrm{o}}$, respectively) were determined using the method published by Tiessen and Moir (2008). The phosphate content in all neutralized extracts was determined by the methods published by Murphy and Riley (1962) and Tiessen and Moir (2008). The amount of each phosphate fraction originating from the added phosphate was calculated by subtracting the control phosphate fraction from the phosphate-added sample fraction.

The phosphate fractions are classified as most labile (Resin-P), less labile $\left(\mathrm{NaHCO}_{3}-\mathrm{P}\right)$, more stable $\mathrm{Fe}$ and $\mathrm{Al}$ associated (NaOH-P), $\mathrm{Fe}$ and $\mathrm{Al}$ associated in soil aggregates (Sonicate/NaOH-P), $\mathrm{Ca}$ associated (HCl-P), and most stable forms (Residual-P; Hedley et al., 1982; Tiessen and Moir, 2008). Note that these fractions are operationally defined, and actual bioavailability of phosphate is determined by interactions between plants and soils (Hinsinger, 2001). Although this fractionation method has limitations in the selectivity for different fractions (Pierzynski et al., 2005; Condron and Newman, 2011), relative lability among Resin- $\mathrm{P}, \mathrm{NaHCO}_{3}-\mathrm{P}$, and the other fractions is maintained. 


\section{Phosphate Release Using Sequential Anion Exchange Membrane Extraction}

The rate of phosphate release was determined using sequential AEM extractions (Sato and Comerford, 2006) for each soil after adding the maximum sorption capacity of phosphate and incubating for $24 \mathrm{~h}$. AEM-extracted-P (called AEM-P) consists mainly of highly mobile phosphate ions, which have a rapid transfer rate between soil and solution. Applying the AEM extraction repeatedly allows the phosphate release rate to be determined from a regression curve, using the exponential equation (Sharpley, 1996; Roboredo and Coutinho, 2006):

$$
\sum_{t=1}^{8} \mathrm{AEM}-\mathrm{P}_{t}=a\left(1-e^{-b t}\right)
$$

where constant $a$ is closely related to the maximum amount of phosphate released using AEM, constant $b$ represents the rate of phosphate release using the AEM strips, and $t$ is the number of extractions. The fitting curve was calculated using SigmaPlot 11.0 software, and provided constants $a$ and $b$. The rate constant $b$ was used to represent the phosphate extractability.

The two AEM strips used for the Resin-P extraction $(2.0 \mathrm{~cm} \times 4.0 \mathrm{~cm})$ were saturated with $0.5 \mathrm{~mol} \mathrm{~L}^{-1} \mathrm{NaHCO}_{3}$ and $30 \mathrm{~mL}$ of deionized water, placed in the samples prepared as described above and shaken for $12 \mathrm{~h}$ at $25^{\circ} \mathrm{C}$. The strips were then removed from the tube, rinsed free of soil particles and placed in another tube filled with $20 \mathrm{~mL}$ of $0.5 \mathrm{~mol} \mathrm{~L}^{-1} \mathrm{HCl}$. The tube was shaken for $12 \mathrm{~h}$ at $25{ }^{\circ} \mathrm{C}$ and the solution was filtered. Phosphate in this filtrate was determined using the method published by Murphy and Riley (1962). New AEM strips were added to the original tube, still containing the soil sample and deionized water, and the extraction procedure was repeated eight times in total, which was sufficient to establish the phosphate release pattern. The amount of released phosphate originating from added phosphate in each sample was calculated by subtracting the AEM-P released from the control from the AEM-P released from the phosphate-added sample.

\section{Surface Area and Porosity Before and After Adding Phosphate}

Specific surface area (SSA) characterization was performed on soil samples with and without phosphate addition using the $\mathrm{N}_{2}$ adsorption method, conducted at liquid nitrogen temperature $(77 \mathrm{~K})$ in a volumetric gas adsorption apparatus (BELSORP-mini II, Bel Japan, Inc., Osaka, Japan) with a diameter detection limit of $0.7 \mathrm{~nm}$. The samples were degassed under vacuum at $70{ }^{\circ} \mathrm{C}$ for $3 \mathrm{~h}$. Because the soil samples contained a wide variety of poorly crystallized minerals, we used a relatively low temperature $\left(70{ }^{\circ} \mathrm{C}\right)$ to remove most of the soil water and to disturb the soil materials as little as possible, which was confirmed by thermal analyses using a simultaneous differential thermal analysis-thermogravimetry (DTA-TG) apparatus 
(DTG60, Shimadzu) and from the reproducibility of the SSAs (data not shown). Pre-treatment at $70{ }^{\circ} \mathrm{C}$ did not decrease the SSA compared with pre-treatment at lower temperatures (e.g. 25 and $50{ }^{\circ} \mathrm{C}$ ) for some selected air-dried soils (data not shown). The grinding and sieving during soil sample preparation might have broken down a large portion of the macro pores, but the effects were not significant for micro-pores for some selected samples (data not shown).

The total surface areas $\left(\mathrm{SSA}_{\text {total }}\right)$ of the samples were calculated with a relative pressure range of $0.05<P / P_{0}<0.30$ using the Brunauer-Emmett-Teller (BET) equation (Brunauer et al., 1938). The SSAs of micro-pores $(\leq 2 \mathrm{~nm})$ were calculated using the t-plot procedure (Lippens and Deboer, 1965) and the SSAs of meso-pores $(2-50 \mathrm{~nm})$ were determined using the Barrett-Joyner-Halenda (BJH) method (Barrett et al., 1951). The meso-pores were classified into 2-nm intervals, i.e. 2-4, 4-6, 6-8, .., $48-50 \mathrm{~nm}$, by linear interpolation of the BJH adsorption data.

\section{Statistics}

Normality of the data was tested by the Kolmogorov-Smirnov test. Spearman rank correlation ( $r s$ ) was used to assess correlations between desorption values and active $\mathrm{Al}$ and $\mathrm{Fe}$ contents or the porosity of the studied soils, using SigmaPlot 11.0 software. Spearman rank correlation was applied because most of the data were not normally distributed.

\section{RESULTS}

\section{Maximum Phosphate Sorption Capacity}

The maximum phosphate sorption capacity (Table 2) was calculated using the Langmuir equation and was used in the subsequent experiments. The phosphate sorption data for all of the soils fitted the equation well $\left(r^{2}>0.98\right)$. The maximum phosphate sorption capacity had a high positive correlation with the active $\mathrm{Al}\left(\mathrm{Al}_{0} ; r s=0.89, P<\right.$ $0.001)$ and $\mathrm{Al}$ plus $\mathrm{Fe}$ content $\left(\mathrm{Al}_{\mathrm{o}}+\mathrm{Fe}_{\mathrm{o}} ; r s=0.91, P<0.001\right.$; Fig. 1$)$, but a relatively weak correlation with active $\mathrm{Fe}\left(\mathrm{Fe}_{\mathrm{o}} ; r s=0.62, P<0.001\right)$. Therefore, most of the following analyses are shown using $\mathrm{Al}_{\mathrm{o}}+\mathrm{Fe}_{\mathrm{o}}$.

\section{Extractability of Added Phosphate}

After adding the maximum phosphate sorption capacity amount to each soil, we evaluated phosphate extractability using Hedley's fractionation method and sequential extraction using an AEM.

The modified Hedley's fractionation method showed that most of the added phosphate was extracted as Resin- $\mathrm{P}, \mathrm{NaHCO}_{3}-\mathrm{P}_{\mathrm{i}}$ and $\mathrm{NaOH}-\mathrm{P}_{\mathrm{i}}$ (Table 2). The percentage of phosphate extracted in each fraction correlated significantly with $\mathrm{Al}_{\mathrm{O}}+$ $\mathrm{Fe}_{\mathrm{o}}$; the most labile phosphate (Resin-P) extract was negatively correlated with $\mathrm{Al}_{\mathrm{o}}+$ 
$\mathrm{Fe}_{\mathrm{o}}(r s=-0.79 P<0.001)$, and the less labile and more stable Fe and Al-associated phosphate $\left(\mathrm{NaHCO}_{3}-\mathrm{P}_{\mathrm{i}}\right.$ and $\left.\mathrm{NaOH}-\mathrm{P}_{\mathrm{i}}\right)$ extracts were positively correlated with $\mathrm{Al}_{\mathrm{o}}+\mathrm{Fe}_{\mathrm{o}}$ ( $r s=0.55, P<0.01$ and $r s=0.55, P<0.01$, respectively). These results indicate that soils with higher $\mathrm{Al}_{\mathrm{o}}+\mathrm{Fe}_{\mathrm{o}}$ have lower proportions of labile Resin-P and higher proportions of less labile $\mathrm{NaHCO}_{3}-\mathrm{P}_{\mathrm{i}}$ and $\mathrm{NaOH}-\mathrm{P}_{\mathrm{i}}$.

Sequential extraction by AEM showed the slow release of added phosphate from soils with high $\mathrm{Al}_{\mathrm{o}}+\mathrm{Fe}_{\mathrm{o}}$ (Table 2). The amounts released fitted the exponential equation well $\left(r^{2} \geq 0.80\right)$ and the calculated constant $b$ had $P$-values less than 0.001 . The amounts of phosphate released in the first extraction were similar to the Resin-P in the Hedley's fractionation method, with a ratio of $1.0 \pm 0.1$ (average \pm standard deviation); the amounts released during the repeated $(8 \times)$ extractions were similar to the sum of Resin- $\mathrm{P}$ and $\mathrm{NaHCO}_{3}-\mathrm{P}_{\mathrm{i}}$, with a ratio of $1.1 \pm 0.1$. The constant $b$, representing phosphate release rate, had a significant negative correlation with $\mathrm{Al}_{\mathrm{o}}+\mathrm{Fe}_{\mathrm{o}}$ ( $r s=-0.91$, $P<0.001$; Fig. 2), indicating that soils with higher $\mathrm{Al}_{\mathrm{o}}+\mathrm{Fe}_{\mathrm{o}}$ have a lower phosphate release rate.

Japanese soils generally showed lower Resin-P proportions and lower release rates than soils from the other regions, with the exception of soils TH4 and ID5 (Thai and Indonesian soils), and soil JP16 (Japanese soil; Table 2). The former were high-altitude (Thai) and volcanic (Indonesian) soils with high $\mathrm{Al}_{\mathrm{o}}+\mathrm{Fe}_{\mathrm{o}}$ (Table 1), and the latter was from Okinawa, an island in south-west Japan with a warmer climate than other parts of Japan. The proportion of Resin-P and the constant $b$ were lower for Japanese soils than for Thai and Indonesian soils with similar $\mathrm{Al}_{\mathrm{o}}+\mathrm{Fe}_{\mathrm{o}}$ levels (Fig. 2).

\section{Specific Surface Area of Total, Micro- and Meso-pores}

The results of the $\mathrm{SSA}_{\text {total }}$ measurements using the $\mathrm{N}_{2}$ adsorption method on samples with and without phosphate sorption treatment are shown in Table 3 . The $\mathrm{SSA}_{\text {total }}$ before treatment correlated positively with $\mathrm{Al}_{\mathrm{o}}+\mathrm{Fe}_{\mathrm{o}}(r s=0.74, P<0.001)$, indicating that active $\mathrm{Al}$ and $\mathrm{Fe}$, because of their large SSAs, contributed to the $\mathrm{SSA}_{\text {total }}$ of the soils. The soil samples after phosphate sorption treatment had lower total SSAs than those before treatment, and the decrease in SSA was called $\Delta \mathrm{SSA}_{\text {total }}$ (Table 3). Such decreases in total SSAs have been seen after the sorption of phosphate on $\mathrm{Al} /$ Fe-based drinking-water treatment residues (Makris et al., 2004). Both $\mathrm{SSA}_{\text {total }}$ and $\triangle \mathrm{SSA}_{\text {total }}$ were positively correlated with the maximum phosphate sorption capacity ( $r S$ $=0.73, P<0.001$ and $r s=0.44, P<0.05$, respectively), suggesting that large $\mathrm{SSA}_{\text {total }}$, derived from active $\mathrm{Al}$ and $\mathrm{Fe}$, contributed to the sorption of phosphate and $\mathrm{SSA}_{\text {total }}$ decreased as phosphate was sorbed.

The SSAs of micro- and meso-pores were also measured using the $\mathrm{N}_{2}$ adsorption method and the results are shown in Table 3. Although micro-pores were not detected in 15 samples (13 Thai and Indonesian samples, the exceptions being ID3 and ID5, and two Japanese samples, JP4 and JP16), small meso-pores (2-4 nm) were present in all of the samples. The samples without micro-pores had low $0.7-4-\mathrm{nm}$ pore 
SSA $\left(\mathrm{SSA}_{0.7-4 \mathrm{~nm}}\right)$. The $\mathrm{SSA}_{0.7-4 \mathrm{~nm}}$ to $\mathrm{SSA}_{\text {total }}\left(\mathrm{SSA}_{0.7-4 \mathrm{~nm}} / \mathrm{SSA}_{\text {total }}\right)$ ratio, which indicates the micro- and small meso-porosity of the samples, was positively correlated with $\mathrm{Al}_{\mathrm{o}}+$ $\mathrm{Fe}_{\mathrm{o}}$ ( $r s=0.76, P<0.001$; Fig. 3 ), indicating that the soils with higher levels of active $\mathrm{Al}$ and Fe were rich in micro- and meso-pores. The $\mathrm{SSA}_{0.7-4 \mathrm{~nm}} / \mathrm{SSA}_{\text {total }}$ ratio also correlated significantly with the proportions of Resin- $\mathrm{P}, \mathrm{NaHCO}_{3}-\mathrm{P}_{\mathrm{i}}$, and $\mathrm{NaOH}-\mathrm{P}_{\mathrm{i}}$ from Hedley's method extracts and the constant $b$ for AEM sequential extraction (Table 4 and Fig. 4 ), indicating that phosphate was more difficult to extract from the samples with higher porosity.

The decrease in the SSAs of the 0.7-4-nm micro- and meso-pores ( $\triangle \mathrm{SSA}_{0.7-4}$ $\mathrm{nm}$ ) because of the phosphate sorption treatment was calculated (Table 3). The soils in which $\Delta \mathrm{SSA}_{0.7-4} \mathrm{~nm}$ was significantly reduced with phosphate treatment had low proportions of Resin-P and high proportions of $\mathrm{NaHCO}_{3}-\mathrm{P}_{i}$ and $\mathrm{NaOH}-\mathrm{P}_{\mathrm{i}}$ by Hedley's method, and small $b$ constants for AEM sequential extraction of phosphate (Table 4 and Fig. 5). These results indicated that soils that sorbed phosphate into their micro- and meso-pores and reduced their $\mathrm{SSA}_{0.7-4 \mathrm{~nm}}$ had a smaller proportion of Resin-P (and a larger proportion of less labile $\mathrm{NaHCO}_{3}-\mathrm{P}_{\mathrm{i}}$ and $\mathrm{NaOH}-\mathrm{P}_{\mathrm{i}}$ ) and had lower values of constant $b$ for the release of sorbed phosphate.

The $\mathrm{SSA}_{0.7-4 \mathrm{~nm}} / \mathrm{SSA}_{\text {total }}$ ratio and $\Delta \mathrm{SSA}_{0.7-4 \mathrm{~nm}}$ were generally high in Japanese soils (from a temperate climate) and low in soils from Thailand and Indonesia (from a tropical climate; Table 3, Figs. 5 and 6). This indicated a high contribution of microand meso-pores to phosphate sorption in the Japanese samples. Exceptions were JP16 and ID5, both mentioned earlier in the section Extractability of Added Phosphate.

\section{Other Soil Properties and Phosphate Extractability}

Other than the parameters listed in Table 4, general soil physicochemical properties that could contribute to phosphate extractability, i.e., clay content, total carbon content, $\mathrm{Fe}_{\mathrm{d}}, \mathrm{Fe}_{\mathrm{d}}-\mathrm{Fe}_{\mathrm{o}}$, and $\mathrm{Fe}_{\mathrm{o}} / \mathrm{Fe}_{\mathrm{d}}$, showed weak or no correlation with the proportion of Resin-P from Hedley's method (the rs values were $-0.20,-0.55,-0.18$, 0.08 and -0.46 , respectively) or the constant $b$ for AEM sequential extraction (the $r s$ values were $-0.13,-0.44,0.03,0.27$ and -0.48 , respectively). This indicated that these properties did not affect phosphate extractability in the samples analyzed.

\section{DISCUSSION}

The results showed that active $\mathrm{Al}$ and Fe reduced the extractability of added phosphate because of phosphate sorption into micro- and small meso-pores. Phosphate sorption treatment resulted in a decrease in $\mathrm{SSA}_{\text {total }}$. When the decrease in micro- and small meso-pore SSA $\left(\Delta \mathrm{SSA}_{0.7-4} \mathrm{~nm}\right)$ was high, the proportion of labile Resin-P and less labile $\mathrm{NaHCO}_{3}-\mathrm{P}_{\mathrm{i}}$ and $\mathrm{NaOH}-\mathrm{P}_{\mathrm{i}}$ measured using Hedley's method were low and high (Table 4), respectively, and the constant $b$ for sequential extraction was low (Fig. 5). $\Delta \mathrm{SSA}_{0.7-4 \mathrm{~nm}}$ was positively correlated with $\mathrm{Al}_{\mathrm{o}}+\mathrm{Fe}_{\mathrm{o}}$ and the $\mathrm{SSA}_{0.7-4 \mathrm{~nm}} / \mathrm{SSA}_{\text {total }}$ ratio, suggesting that sorption into micro- and meso-pores occurred in soils with high active 
$\mathrm{Al}$ and Fe contents and high porosities. The desorption of phosphate might be the same in all pore sizes but the diffusion of the desorbed phosphate to bulk solution might be limited in the micro- and small meso-pores.

The Japanese soil samples had high porosity (Fig. 3) and the decrease in the micro- and meso-pore SSAs with phosphate treatment was greater in these samples than in the Thai and Indonesian samples (Fig. 6). When the amount of $\mathrm{Al}_{\mathrm{o}}+\mathrm{Fe}_{\mathrm{o}}$ was similar, the proportion of Resin-P measured using Hedley's method and the constant $b$ for sequential extraction were lower for the Japanese soils than for the other soils (Table 2 and Fig. 2). For the Thai and Indonesian soil samples the amounts of 0.7-4-nm micro and meso-pores and the reduced amounts after phosphate treatment were small (Table 3 and Fig. 6), indicating that this pore size range appeared to have less effect on the sorption and extraction of phosphate in these soils. Short-range-ordered minerals, i.e., allophone and imogolite, contributed to the large micro- and small meso-pore surface areas, their decrease with phosphate sorption, and the phosphate extractability in the volcanic soils from Japan. The $\mathrm{Si}_{\mathrm{o}}$ contents were similar in the other Japanese soils and the Thai and Indonesian soils (Table 1) and therefore they appear to contain little, if any, allophone and imogolite. The crystallinity of the $\mathrm{Al}$ and Fe oxides/hydroxides might be lower in the Japanese soils because they were younger soils such as Inceptisols and Andisols, with interference in Al and Fe crystallization by organics and Si (Hsu, 1989; Schwertmann and Taylor, 1989), resulting in higher soil porosity, the decrease in microand meso-pores with phosphate sorption and lower phosphate extractability.

Using synthetic materials, the inhibitory effect of phosphate sorption on the inside surface of micro- and meso-pores on its subsequent extraction has been indicated by several studies, although experimental data on their effect in soils are still scarce. Cabrera et al. (1981) suggested that the low extractability and slow release rate of phosphate added to lepidocrocite was because of its micro-pores. Strauss et al. (1997) observed that with poorly crystallized goethite it was necessary to dissolve much more iron than with crystalline goethite to achieve a similar ability to remove phosphate, which they assumed was because of the penetration of phosphate into micro- and meso-pores and sorption on internal surfaces. Makris et al. (2004) suggested that the micro-pores of drinking-water treatment residue resist phosphate release over long periods, and after phosphate treatment they observed increases in the relative phosphate concentrations in the interior of the particles $(\sim 60 \mu \mathrm{m}$ depth $)$, a decrease in pore size distribution and low phosphate extractability. Phosphate sorption into micro- and meso-pores in soils has been assumed to be inhibitory to phosphate release (Arai and Sparks, 2007), but micro- and meso-pore SSA data for soils are lacking. Using soils formed under natural conditions (though they were dried and sieved during the sample preparation), our study showed the inhibitory effect of phosphate sorption to the inside of micro- and meso-pores on its subsequent extraction.

The availability of phosphate to plants and the potential for phosphate leaching 
after application to agricultural land might differ depending on particle surface porosity derived from active $\mathrm{Al}$ and $\mathrm{Fe}$ and phosphate sorption into micro- and meso-pores. According to Barros et al. (2005), lower soil loading with phosphate leads to lower phosphate extractability. This should mean that if the same amount of phosphate was applied to the soils in our study, the difference between soils with low and high active $\mathrm{Al}$ and Fe contents (and therefore small and large maximum sorption capacities) would become clearer, and soils with high active Al and Fe contents would release sorbed phosphate more slowly. The mobility of applied phosphate appeared to differ between the Japanese and the Thai and Indonesian soils even when the amount of active Al and Fe was similar. The Japanese soils were rich in micro- and meso-pores that sorbed phosphate inside the pores, whereas the Thai and Indonesian soils had low porosity and larger pores, and the outer surfaces probably sorbed the most phosphate. This is likely to result in higher phosphate mobility in the Thai and Indonesian soils than the Japanese soils.

The effects of aging and the competitive sorption of organic matter on phosphate extractability should be considered under field conditions, as well as the porosity of the soils. Sorbed phosphate becomes more strongly held to soils with time, which might be explained by the precipitation of phosphate and diffusion into microand meso-pores (Arai and Sparks, 2007). In this study the duration of phosphate sorption treatment was $24 \mathrm{~h}$, in which time-rapid sorption onto soils is the main mechanism of phosphate sorption and the degree of precipitation would be limited (McGechan, 2002). Li et al. (2013) showed that the formation of binuclear inner-sphere surface complexes was the dominant mechanism for phosphate sorption on aluminum oxides/hydroxides during reaction times ranging from $15 \mathrm{~min}$ to 21 days. The competitive sorption of organic anions could be important for the release of phosphate in the field (Easterwood and Sartain, 1990; Hinsinger, 2001; Guppy et al., 2005), although the affinity between phosphate and $\mathrm{Al}$ and Fe oxides/hydroxides is stronger than between organic anions and the oxides/hydroxides (Hinsinger, 2001; Borggaard et al., 2005).

Physical disruption of soils might occur during the process of air-drying the moist soil samples and during shaking in the extraction procedures. Although heating moist samples of amorphous $\mathrm{Al}(\mathrm{OH})_{3}$ and ferrihydrite to 40 and $80{ }^{\circ} \mathrm{C}$, respectively, decreased the SSA, especially that of micro-pores (Kaiser and Guggenberger, 2003), our pre-treatment at $70{ }^{\circ} \mathrm{C}$ did not show decreased SSA compared with pre-treatment at lower temperatures (e.g. 25 and $50{ }^{\circ} \mathrm{C}$ ) for some selected air-dried soils (data not shown). The reduction in porosity might occur during air-drying when the soils contain moisture. Shaking during the extractions might also physically disrupt soils and affect phosphate extraction. These drying and shaking steps might constitute the difference in phosphate behavior between the field and the laboratory.

In this study we presented experimental data on the inhibitory effect of micro- 
and small meso-pores on phosphate release using various types of soils. We showed that phosphate release from soils with high porosity was more difficult than from soils with low porosity. Estimations of phosphate release for plant nutrition or phosphate leaching in soils should consider the porosity of soils. Studies of the effect of soil porosity on the aging and competition of phosphate with organic matter for micro- and meso-pores will improve our understanding of the dynamics of phosphate applied to soils, leading to improvements in fertilizer management.

\section{ACKNOWLEDGMENTS}

This work was partially supported by JSPS KAKENHI Grant Numbers 24228007 and 26660048.

\section{REFERENCES}

Addiscott, T.M., and D. Thomas. 2000. Tillage, mineralization and leaching: phosphate. Soil \& Tillage Research 53:255-273.

Arai, Y., and D.L. Sparks. 2007. Phosphate reaction dynamics in soils and soil components: A muiltiscale approach, p. 135-179, In D. L. Sparks, (ed.) Advances in Agronomy, Vol 94, Vol. 94.

Barrett, E.P., L.G. Joyner, and P.P. Halenda. 1951. The determination of pore volume and area distributions in porous substances. I. computations from nitrogen isotherms. J. Am. Chem. Soc. 73:373-380.

Barros, N.F., N.B. Comerford, and N.F. Barros. 2005. Phosphorus sorption, desorption and resorption by soils of the Brazilian Cerrado supporting eucalypt. Biomass Bioenerg. 28:229-236.

Blakemore, L.C., P.L. Searle, and B.K. Daly. 1981. Methods for chemical analysis of soils. New Zealand Soil Bureau Scientific Report 10A DSIR, New Zealand.

Blakemore, L.C., P.L. Searle, and B.K. Daly. 1987. Soil pH, p. 9 - 12 Methods for Chemical Analysis of Soils. NZ Soil Bureau, Department of Scientific and Industrial Research, Lower Hutt, New Zealand.

Borggaard, O.K., B. Raben-Lange, A.L. Gimsing, and B.W. Strobel. 2005. Influence of humic substances on phosphate adsorption by aluminium and iron oxides. Geoderma 127:270-279.

Brunauer, S., P.H. Emmett, and E. Teller. 1938. Adsorption of gases in multimolecular layers. J. Am. Chem. Soc. 60:309-319.

Cabrera, F., P. Dearambarri, L. Madrid, and C.G. Toca. 1981. Desorption of phosphate from iron-oxides in relation to equilibrium $\mathrm{pH}$ and porosity. Geoderma 26:203-216.

Colombo, C., V. Barron, and J. Torrent. 1994. Phosphate adsorption and desorption in relation to morphology and crystal properties of synthetic hematites. Geochim. Cosmochim. Acta 58:1261-1269. 
Condron, L.M., and S. Newman. 2011. Revisiting the fundamentals of phosphorus fractionation of sediments and soils. Journal of Soils and Sediments 11:830-840.

Easterwood, G.W., and J.B. Sartain. 1990. Clover residue effectiveness in reducing orthophosphate sorption on ferric hydroxide coated soil. Soil Sci. Soc. Am. J. 54:1345-1350.

Everett, D.H. 1972. Manual of symbols and terminology for physicochemical quantities and units, Appendix II: definitions,terminology and symbols in colloid and surface chemistry. Pure Appl. Chem. 31:577-638.

Fernandes, M.L., and J. Coutinho. 1997. Anion and cation exchange resin membranes to assess the phosphorus status of some Portuguese soils. Commun. Soil Sci. Plant Anal. 28:483-495.

Freese, D., S. Vanderzee, and W.H. Vanriemsdijk. 1992. Comparison of different models for phosphate sorption as a function of the iron and aluminum-Oxides of soils. J. Soil Sci. 43:729-738.

Gee, G.W., and D. Or. 2002. Particle-size analysis, p. 255-293, In J. H. Dane and G. C. Topp, (ed.) Methods of Soil Analysis. Part 4. Physical Methods. SSSA, Madison, WI.

Guppy, C.N., N.W. Menzies, P.W. Moody, and F.P.C. Blamey. 2005. Competitive sorption reactions between phosphorus and organic matter in soil: a review. Aust. J. Soil Res. 43:189-202.

Hartono, A., S. Funakawa, and T. Kosaki. 2006. Transformation of added phosphorus to acid upland soils with different soil properties in Indonesia. Soil Sci. Plant Nutr. 52:734-744.

Hedley, M.J., J.W.B. Stewart, and B.S. Chauhan. 1982. Changes in inorganic and organic soil phosphorus fractions induced by cultivation practices and by laboratory incubations. Soil Sci. Soc. Am. J. 46:970-976.

Hinsinger, P. 2001. Bioavailability of soil inorganic P in the rhizosphere as affected by root-induced chemical changes: a review. Plant Soil 237:173-195.

Hsu, P.H. 1989. Aluminum hydroxides and oxyhydroxides, p. 331-378, In J. B. Dixon and S. B. Weed, (ed.) Minerals in Soil Environments, 2nd ed. Soil Science Society of America, Madison, WI, USA.

Jeffries, C.D. 1946. A rapid method for the removal of free iron oxides in soil prior to petrographic analysis. Soil Sci. Soc. Am. Proc. 10:211-212.

Kaiser, K., and G. Guggenberger. 2003. Mineral surfaces and soil organic matter. Eur. J. Soil Sci. 54:219-236.

Li, W., X. Feng, Y. Yan, D.L. Sparks, and B.L. Phillips. 2013. Solid-state NMR spectroscopic study of phosphate sorption mechanisms on aluminum (hydr)oxides. Environ. Sci. Technol. 47:8308-8315.

Lippens, B.C., and J.H. Deboer. 1965. Studies on pore systems in catalysts. V. the $t$ method. J. Catal. 4:319-323. 
Makris, K.C., W.G. Harris, G.A. O'connor, and T.A. Obreza. 2004. Phosphorus immobilization in micropores of drinking-water treatment residuals: implications of long-term stability. Communications in Soil Science and Plant AnalysisPlant and SoilEnvironmental Science \& Technology 38:6590-6596.

McGechan, M.B. 2002. Sorption of phosphorus by soil, part 2: measurement methods, results and model parameter values. Biosyst. Eng. 82:115-130.

McGechan, M.B., and D.R. Lewis. 2002. Sorption of phosphorus by soil, part 1: principles, equations and models. Biosyst. Eng. 82:1-24.

Mehra, O.P., and M.L. Jackson. 1960. Iron oxide removal from soils and clays by a dithionite-citrate system buffered with sodium bicarbonate. Proceedings of the 7th National Conference on Clays and Clay Minerals:317-327.

Murphy, J., and J.P. Riley. 1962. A modified single solution method for the determination of phosphate in natural waters. Anal. Chim. Acta 27:31-36.

Negassa, W., and P. Leinweber. 2009. How does the Hedley sequential phosphorus fractionation reflect impacts of land use and management on soil phosphorus: A review. Journal of Plant Nutrition and Soil Science-Zeitschrift Fur Pflanzenernahrung Und Bodenkunde 172:305-325.

Nuernberg, N.J., J.E. Leal, and M.E. Sumner. 1998. Evaluation of an anion-exchange membrane for extracting plant available phosphorus in soils. Commun. Soil Sci. Plant Anal. 29:467-479.

Parfitt, R.L. 1978. Anion adsorption by soils and soil materials Advances in Agronomy, Vol. 30. Academic Press, Inc.

Pierzynski, G.M., R.W. McDowell, and J.T. Sims. 2005. Chemistry, cycling, and potential movement of inorganic phosphorus in soils, p. 53-86, In J. T. Sims and A. N. Sharpley, (ed.) Phoshprus: Agriculture and the Environment. ASA, CSSA, SSSA, Madison, Wisconsin, USA.

Redel, Y.D., R. Rubio, J.L. Rouanet, and F. Borie. 2007. Phosphorus bioavailability affected by tillage and crop rotation on a Chilean volcanic derived Ultisol. Geoderma 139:388-396.

Roboredo, M., and J. Coutinho. 2006. Chemical characterization of inorganic phosphorus desorbed by ion exchange membranes in short- and long-term extraction periods. Commun. Soil Sci. Plant Anal. 37:1611-1626.

Sato, S., and N.B. Comerford. 2006. Assessing methods for developing phosphorus desorption isotherms from soils using anion exchange membranes. Plant Soil 279:107-117.

Schwertmann, U., and R.M. Taylor. 1989. Iron oxides, p. 379-438, In J. B. Dixon and S. B. Weed, (ed.) Minerals in Soil Environments, 2nd ed. Soil Science Society of America, Madison, WI, USA.

Shang, C., and L. Zelazny. 2008. Selective dissolution techniques for mineral analysis of soils and sediments, p. 33-80, In A. L. Ulery and L. R. Drees, (ed.) Methods 
of Soil Analysis Part 5 Mineralogical Methods. Soil Science Society of America, Inc., Madison, Wisconsin, USA.

Sharpley, A.N. 1983. Effect of soil properties on the kinetics of phosphorus desorption. Soil Sci. Soc. Am. J. 47:462-467.

Sharpley, A.N. 1996. Availability of residual phosphorus in manured soils. Soil Sci. Soc. Am. J. 60:1459-1466.

Soil Survey Staff. 1999. Soil Taxonomy. second ed. ed. USDA-NRCS, Washington, DC.

Strauss, R., G.W. Brummer, and N.J. Barrow. 1997. Effects of crystallinity of goethite: II. Rates of sorption and desorption of phosphate. Eur. J. Soil Sci. 48:101-114.

Tiessen, H., and J.O. Moir. 2008. Characterization of available P by sequential extraction, p. 293-306, In M. R. Carter and E. G. Gregorich, (ed.) Soil Sampling and Methods of Analysis, 2nd ed. CRC Press, Boca Raton, FL.

Torrent, J., U. Schwertmann, and V. Barron. 1992. Fast and slow phosphate sorption by goethite-rich natural materials. Clays Clay Miner. 40:14-21.

Wada, K., and T. Kawano. 1978. Use of Jeffries acid oxalate treatment in particle-size analyses of Ando soils. Geoderma 20:215-224. 


\section{FIGURE LEGENDS}

FIG. 1. Relationship between acid oxalate-extractable $\mathrm{Al}$ and $\mathrm{Fe}$ contents $\left(\mathrm{Al}_{\mathrm{o}}\right.$ and $\left.\mathrm{Fe}_{\mathrm{o}}\right)$ and maximum phosphate sorption capacity (A: large scale; B: small scale).

FIG. 2. Relationship between acid oxalate-extractable $\mathrm{Al}$ and $\mathrm{Fe}$ contents $\left(\mathrm{Al}_{\mathrm{o}}\right.$ and $\left.\mathrm{Fe}_{\mathrm{o}}\right)$ and the constant $b$ representing phosphate release rate using an anion exchange membrane.

FIG. 3. Relationship between acid oxalate-extractable $\mathrm{Al}$ and $\mathrm{Fe}$ contents $\left(\mathrm{Al}_{\mathrm{o}}\right.$ and $\left.\mathrm{Fe}_{\mathrm{o}}\right)$ and the percentage of SSAs of micro- and meso-pores $(0.7-4 \mathrm{~nm})\left(\mathrm{SSA}_{0.7-4 \mathrm{~nm}}\right)$ relative to the total SSA $\left(\mathrm{SSA}_{\text {total }}\right)$.

FIG. 4. Relationship between the percentage of SSAs of micro- and meso-pores (0.7-4 $\mathrm{nm})\left(\mathrm{SSA}_{0.7-4 \mathrm{~nm}}\right)$ relative to the total $\mathrm{SSA}\left(\mathrm{SSA}_{\text {total }}\right)$ and the constant $b$ representing phosphate release rate using an anion exchange membrane.

FIG. 5. Relationship between the decrease in specific surface area of micro- and meso-pores $(0.7-4 \mathrm{~nm})$ after phosphate sorption treatment $\left(\Delta \mathrm{SSA}_{0.7-4 \mathrm{~nm}}\right)$ and the constant $b$ representing phosphate release rate using an anion exchange membrane.

FIG. 6. Relationship between the decrease in total specific surface area $\left(\triangle \mathrm{SSA}_{\text {total }}\right)$ and the decrease in SSAs of micro- and meso-pores $(0.7-4 \mathrm{~nm})$ after phosphate sorption treatment $\left(\triangle \mathrm{SSA}_{0.7-4 \mathrm{~nm}}\right)$. 
A

B
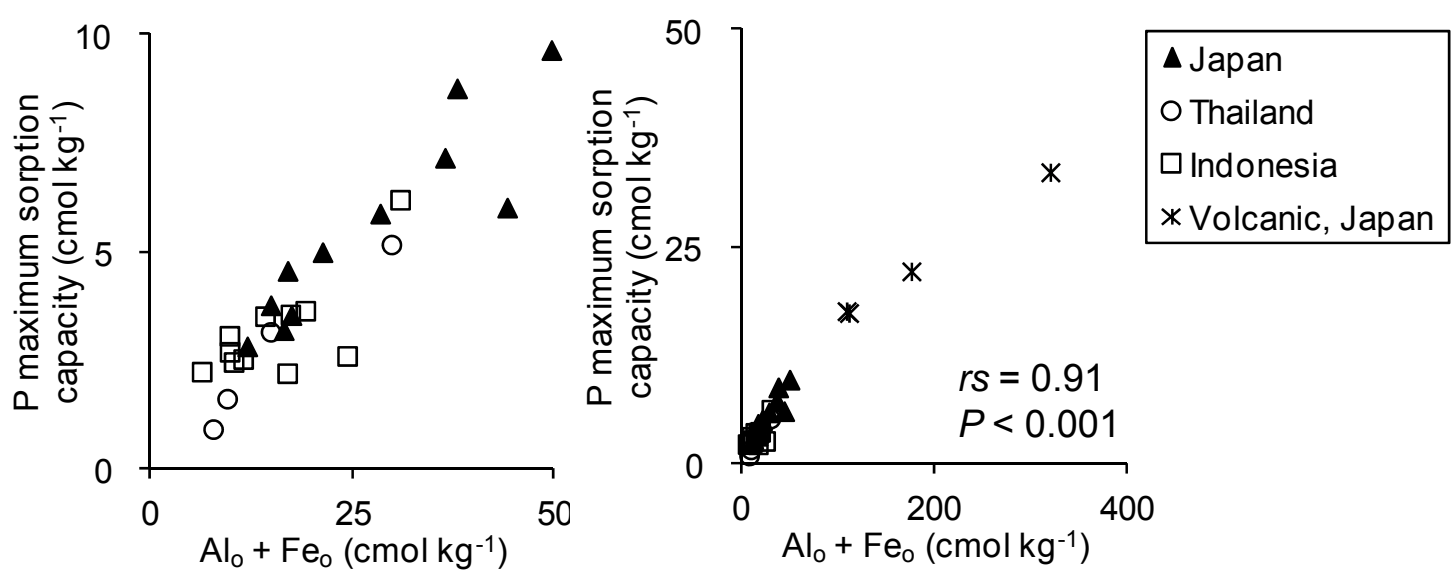

FIG. 1. Relationship between acid oxalate-extractable $\mathrm{Al}$ and $\mathrm{Fe}$ contents $\left(\mathrm{Al}_{\mathrm{o}}\right.$ and $\left.\mathrm{Fe}_{\mathrm{o}}\right)$ and maximum phosphate sorption capacity (A: large scale; B: small scale). 


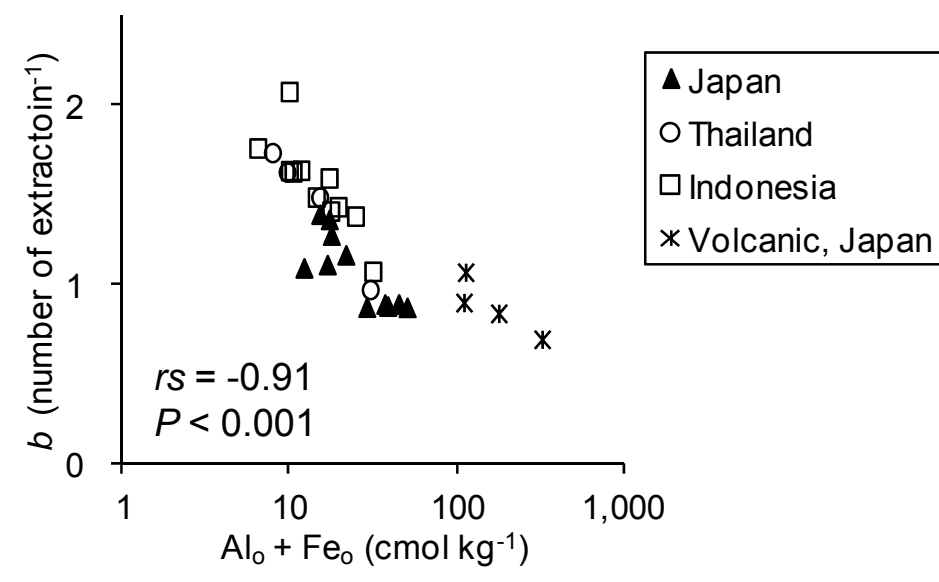

FIG. 2. Relationship between acid oxalate-extractable $\mathrm{Al}$ and $\mathrm{Fe}$ contents $\left(\mathrm{Al}_{\mathrm{o}}\right.$ and $\left.\mathrm{Fe}_{\mathrm{o}}\right)$ and the constant $b$ representing phosphate release rate using an anion exchange membrane. 


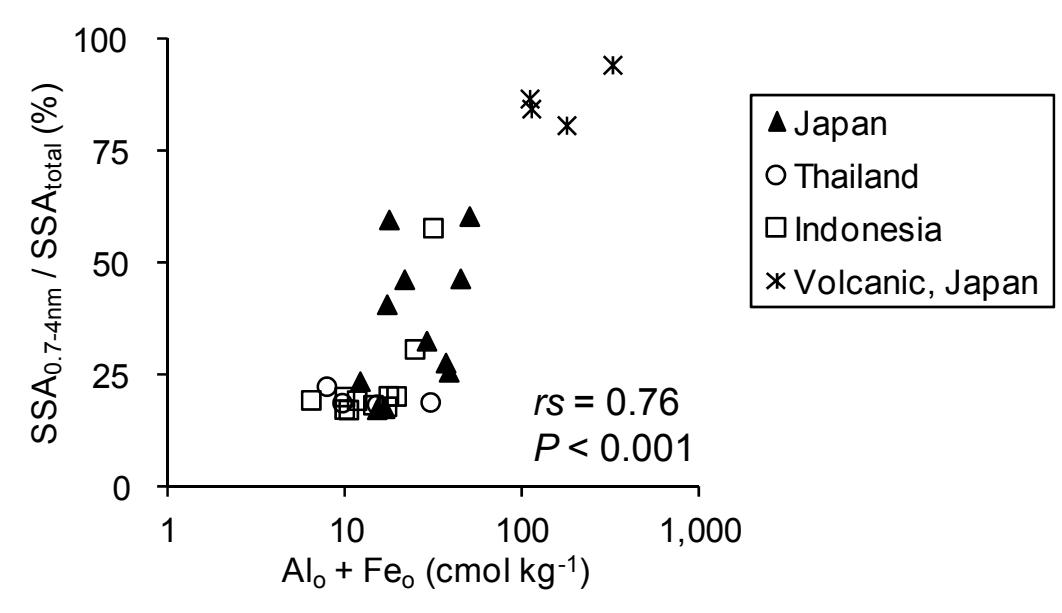

FIG. 3. Relationship between acid oxalate-extractable $\mathrm{Al}$ and $\mathrm{Fe}$ contents $\left(\mathrm{Al}_{\mathrm{o}}\right.$ and $\left.\mathrm{Fe}_{\mathrm{o}}\right)$ and the percentage of SSAs of micro- and meso-pores $(0.7-4 \mathrm{~nm})\left(\mathrm{SSA}_{0.7-4 \mathrm{~nm}}\right)$ relative to the total SSA $\left(\mathrm{SSA}_{\text {total }}\right)$. 


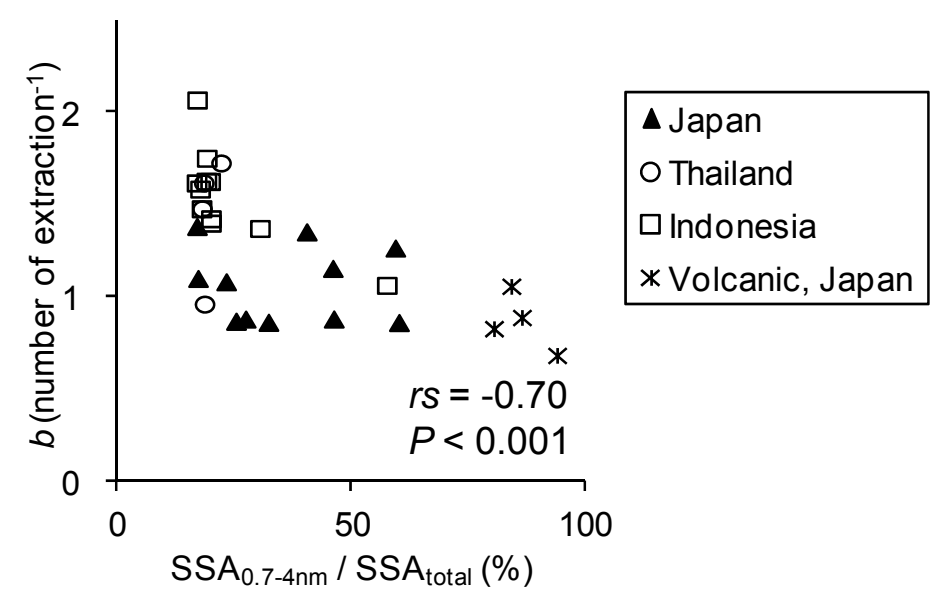

FIG. 4. Relationship between the percentage of SSAs of micro- and meso-pores (0.7-4 $\mathrm{nm})\left(\mathrm{SSA}_{0.7-4 \mathrm{~nm}}\right)$ relative to the total SSA $\left(\mathrm{SSA}_{\text {total }}\right)$ and the constant $b$ representing phosphate release rate using an anion exchange membrane. 


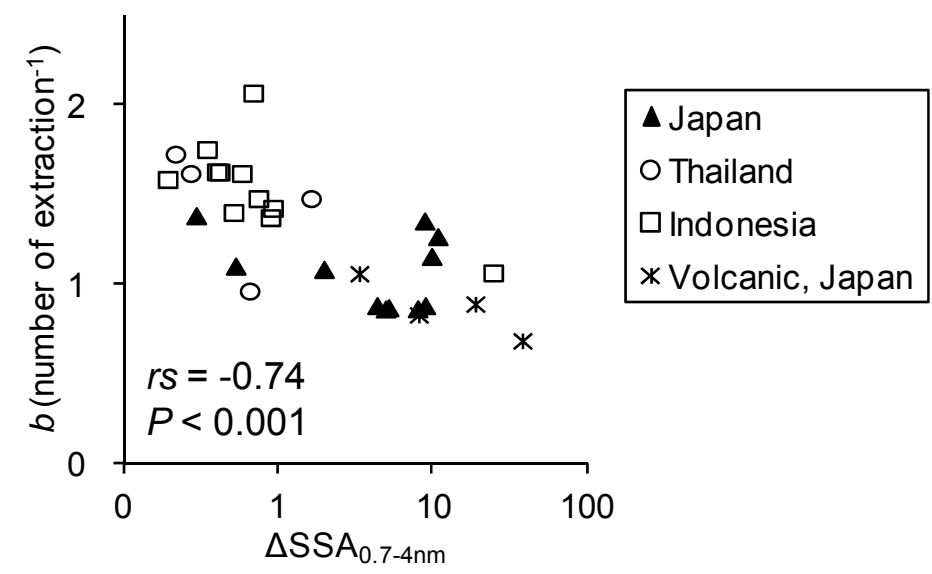

FIG. 5. Relationship between the decrease in specific surface area of micro- and mesopores $(0.7-4 \mathrm{~nm})$ after phosphate sorption treatment $\left(\Delta \mathrm{SSA}_{0.7-4 \mathrm{~nm}}\right)$ and the constant $b$ representing phosphate release rate using an anion exchange membrane. 


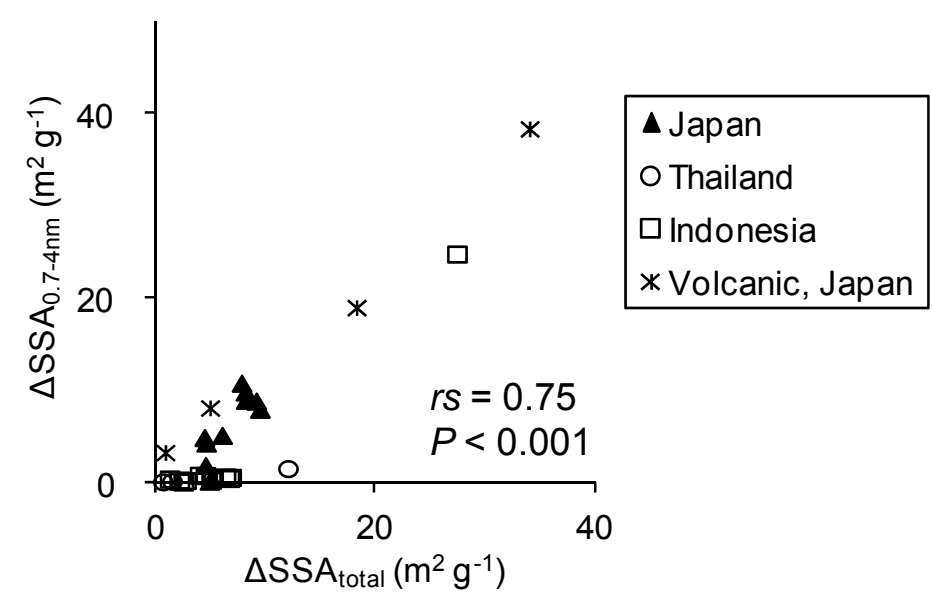

FIG. 6. Relationship between the decrease in total specific surface area $\left(\triangle \mathrm{SSA}_{\text {total }}\right)$ and the decrease in SSAs of micro- and meso-pores $(0.7-4 \mathrm{~nm})$ after phosphate sorption treatment $\left(\Delta \mathrm{SSA}_{0.7-4 \mathrm{~nm}}\right)$. 
Table 1. Descriptive information and the physical and chemical properties of the studied soils $\uparrow$

\begin{tabular}{|c|c|c|c|c|c|c|c|c|c|c|c|c|c|}
\hline Region & Sample & Soil classification $\dagger \dagger$ & Horizon & $\begin{array}{l}\text { Depth } \\
\text { cm }\end{array}$ & $\mathrm{pH}\left(\mathrm{H}_{2} \mathrm{O}\right)$ & $\begin{array}{c}\text { Total C } \\
\mathrm{g} \mathrm{kg}^{-1}\end{array}$ & $\begin{array}{c}\text { Clay } \\
\%\end{array}$ & $\begin{array}{c}\mathrm{Al}_{\mathrm{o}} \\
\mathrm{g} \mathrm{kg}^{-1}\end{array}$ & $\begin{array}{c}\mathrm{Fe}_{\mathrm{o}} \\
\mathrm{g} \mathrm{kg}^{-1}\end{array}$ & $\begin{array}{c}\mathrm{Si}_{\mathrm{o}} \\
\mathrm{g} \mathrm{kg}^{-1}\end{array}$ & $\begin{array}{c}\mathrm{Fe}_{\mathrm{d}} \\
\mathrm{g} \mathrm{kg}^{-1}\end{array}$ & $\begin{array}{c}\mathrm{Al}_{\mathrm{o}}+1 / 2 \mathrm{Fe}_{\mathrm{o}} \\
\mathrm{g} \mathrm{kg}^{-1}\end{array}$ & $\begin{array}{l}\text { Total P } \\
\mathrm{g} \mathrm{kg}^{-1}\end{array}$ \\
\hline \multicolumn{14}{|l|}{ Thailand } \\
\hline & TH1 & Typic Haplustult & $\mathrm{Bt}$ & $30-40$ & 5.4 & 6.5 & 33 & 2.0 & 4.1 & 0.5 & 23 & 4.1 & 0.40 \\
\hline & $\mathrm{TH} 2$ & Typic Haplustult & $\mathrm{Bt}$ & $30-40$ & 5.5 & 8.2 & 46 & 1.3 & 2.5 & 0.4 & 20 & 2.6 & 0.18 \\
\hline & TH3 & Ultic Haplustalf & $\mathrm{Bt}$ & $30-40$ & 5.5 & 9.5 & 32 & 0.9 & 2.4 & 0.4 & 13 & 2.1 & 0.27 \\
\hline & TH4 & Ustic Haplohumult & $\mathrm{Bt}$ & $30-40$ & 5.5 & 14.9 & 49 & 4.8 & 6.8 & 0.6 & 55 & 8.2 & 0.70 \\
\hline \multicolumn{14}{|c|}{ Indonesia } \\
\hline & ID3 & Ultic Hapludalf & Bw & $6-19$ & 5.4 & 17.1 & 35 & 3.6 & 6.2 & 1.2 & 56 & 6.7 & 0.32 \\
\hline & ID5 & Typic Dystrudept & Bw & $35-63$ & 5.3 & 5.0 & 33 & 4.6 & 7.8 & 1.0 & 45 & 8.5 & 0.41 \\
\hline & ID7 & Typic Hapludult & $\mathrm{Bt}$ & $30-55$ & 4.8 & 6.7 & 50 & 2.3 & 3.2 & 0.3 & 34 & 3.9 & 0.18 \\
\hline & ID9 & Lithic Udorthent & $\mathrm{C}$ & $10-40$ & 5.5 & 7.4 & 20 & 2.5 & 4.2 & 0.7 & 12 & 8.8 & 0.27 \\
\hline & ID10 & Typic Paleudult & $\mathrm{Bt}$ & $35-55$ & 4.3 & 7.3 & 50 & 1.6 & 7.5 & 0.5 & 26 & 5.3 & 0.15 \\
\hline & ID12 & Typic Paleudult & $\mathrm{Bt}$ & $30-60$ & 4.3 & 4.0 & 45 & 0.9 & 1.7 & 0.3 & 21 & 1.7 & 0.07 \\
\hline & ID13 & Typic Paleudult & $\mathrm{Bt}$ & $30-60$ & 4.4 & 3.7 & 45 & 2.1 & 1.1 & 0.3 & 28 & 2.6 & 0.13 \\
\hline & ID14 & Typic Paleudult & $\mathrm{E}$ & $3-20$ & 3.9 & 13.5 & 36 & 1.3 & 2.8 & 0.3 & 23 & 2.7 & 0.30 \\
\hline & ID15 & Typic Paleudalf & $\mathrm{BE}$ & $7-20$ & 4.9 & 13.0 & 39 & 1.2 & 7.1 & 0.5 & 30 & 4.8 & 0.30 \\
\hline & ID17 & Typic Haplohumult & $\mathrm{Bt}$ & $20-40$ & 4.7 & 9.1 & 38 & 1.8 & 2.6 & 0.2 & 24 & 3.1 & 0.17 \\
\hline & ID18 & Typic Hapludult & $\mathrm{Bt}$ & $40-60$ & 4.5 & 5.6 & 32 & 1.5 & 2.6 & 0.3 & 19 & 2.8 & 0.20 \\
\hline Japan & JP1 & Typic Dystrudept & $\mathrm{BC}$ & $40-55+$ & 5.0 & 7.6 & 41 & 3.9 & 1.4 & 0.7 & 13 & 4.6 & 0.17 \\
\hline & JP4 & Typic Dystrudept & $\mathrm{AB}$ & $9-20$ & 4.6 & 11.2 & 35 & 2.8 & 3.4 & 0.4 & 11 & 4.5 & 0.08 \\
\hline & JP6 & Typic Dystrudept & $\mathrm{Bw}$ & $23-39$ & 4.5 & 11.6 & 46 & 4.7 & 6.1 & 0.5 & 71 & 7.8 & 0.44 \\
\hline & JP9 & Andic Dystrudept & $\mathrm{BC}$ & $50-73$ & 4.8 & 14.0 & 47 & 8.5 & 3.6 & 1.0 & 22 & 10.3 & 0.17 \\
\hline & JP11 & Typic Dystrudept & Bw2 & $63-87$ & 5.3 & 2.8 & 49 & 3.7 & 4.3 & 0.0 & 30 & 5.8 & 0.19 \\
\hline & JP12 & Andic Dystrudept & $\mathrm{BC}$ & $42-50+$ & 4.7 & 7.4 & 42 & 3.1 & 3.3 & 0.2 & 16 & 4.8 & 0.20 \\
\hline & JP13 & Typic Fulvudand & $\mathrm{C}$ & $62-70+$ & 4.8 & 16.3 & 41 & 9.6 & 7.9 & 0.6 & 17 & 13.5 & 0.39 \\
\hline & JP16 & Typic Dystrudept & $\mathrm{BC}$ & $50-105+$ & 4.7 & 3.6 & 34 & 3.6 & 0.8 & 0.2 & 56 & 4.0 & 0.14 \\
\hline & JP17 & Typic Dystrudept & $\mathrm{BC}$ & $48-57$ & 4.8 & 13.0 & 46 & 6.6 & 6.7 & 0.7 & 25 & 10.0 & 0.25 \\
\hline & JP18 & Lithic Haplorthod & Bs & $19-38$ & 4.3 & 15.0 & 38 & 6.6 & 11.0 & 0.6 & 56 & 12.1 & 0.27 \\
\hline & JP19 & Typic Dystrudept & B1 & $20-38$ & 4.8 & 15.0 & 39 & 2.5 & 1.5 & 0.0 & 35 & 3.3 & 0.39 \\
\hline \multicolumn{14}{|c|}{ Volcanic, Japan } \\
\hline & JP15 & Acrudoxic Melanudand & Bw2 & $76-93+$ & 5.3 & 18.4 & 40 & 73.6 & 26.2 & 37.3 & 31 & 86.7 & 0.97 \\
\hline & JP20 & Hydric Melanudand & $\mathrm{C}$ & $72-87$ & 6.3 & 13.8 & 44 & 44.6 & 6.0 & 21.6 & 19 & 47.5 & 0.48 \\
\hline & JP21 & Typic Hapludand & $\mathrm{C}$ & $112-140$ & 6.4 & 6.9 & 33 & 27.4 & 5.4 & 14.3 & 17 & 30.1 & 0.47 \\
\hline & JP22 & Hydric Melanudand & $\mathrm{C}$ & $90-120$ & 6.1 & 8.8 & 33 & 27.2 & 4.4 & 13.9 & 17 & 29.4 & 0.38 \\
\hline
\end{tabular}

$\dagger \mathrm{Al}_{0}, \mathrm{Fe}_{\mathrm{o}}, \mathrm{Si}_{\mathrm{o}}$ : acid ammonium oxalate-extractable $\mathrm{Al}, \mathrm{Fe}, \mathrm{Si} ; \mathrm{Fe}_{\mathrm{d}}$ : dithionite-citrate-bicarbonate extractable $\mathrm{Fe}$.

$\dagger \dagger$ According to Soil Taxonomy (Soil Survey Staff, 1999). 
Table 2. Results of Hedley's fractionation and extraction by anion exchange membrane $\dagger$

\begin{tabular}{|c|c|c|c|c|c|c|c|c|c|c|c|c|c|}
\hline \multirow{2}{*}{ Region } & \multirow{2}{*}{ Sample } & \multirow{2}{*}{$\begin{array}{l}\mathrm{Al}_{\mathrm{o}}+\mathrm{Fe}_{\mathrm{o}} \\
\mathrm{cmol} \mathrm{kg}^{-1}\end{array}$} & \multirow[b]{2}{*}{$\begin{array}{l}\text { P maximum } \\
\text { sorption } \\
\text { capacity } \\
\text { cmol kg }^{-1}\end{array}$} & \multicolumn{9}{|c|}{ Hedley's fractionation } & \multirow[b]{2}{*}{$\begin{array}{l}\text { Rate constant } \\
\text { for desorption } \\
\text { with AEM } \\
\quad \text { extraction } \\
\text { ext }\end{array}$} \\
\hline & & & & $\begin{array}{l}\text { Resin } \\
-\mathrm{P} \\
\quad \% \\
\end{array}$ & \begin{tabular}{l}
$\mathrm{NaHCO}_{3}$ \\
$-\mathrm{P}_{\mathrm{i}}$ \\
\multicolumn{1}{c}{$\%$} \\
\end{tabular} & 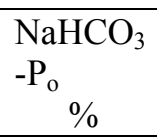 & \begin{tabular}{l}
$\mathrm{NaOH}$ \\
$-\mathrm{P}_{\mathrm{i}}$ \\
\multicolumn{1}{c}{$\%$}
\end{tabular} & $\begin{array}{l}\mathrm{NaOH} \\
-\mathrm{P}_{\mathrm{o}} \\
\quad \% \\
\end{array}$ & $\begin{array}{ll}\text { sonic } \mathrm{NaOH} \\
-\mathrm{P}_{\mathrm{i}} & \\
& \% \\
\end{array}$ & $\begin{array}{l}\text { sonic } \mathrm{NaOH} \\
-\mathrm{P}_{\mathrm{o}} \\
\\
\%\end{array}$ & $\begin{array}{l}\mathrm{HCl} \\
-\mathrm{P} \\
\quad \% \\
\end{array}$ & $\begin{array}{l}\text { Residual } \\
-\mathrm{P} \\
\quad \% \\
\end{array}$ & \\
\hline \multicolumn{14}{|l|}{ Thailand } \\
\hline & TH1 & 14.8 & 3.1 & 67 & 14 & 0 & 17 & 0 & 1 & 0 & 0 & 0 & 1.48 \\
\hline & $\mathrm{TH} 2$ & 9.5 & 1.6 & 76 & 5 & 4 & 13 & 1 & 1 & 0 & 0 & 0 & 1.62 \\
\hline & TH3 & 7.7 & 0.9 & 70 & 10 & 1 & 12 & 1 & 0 & 0 & 0 & 6 & 1.73 \\
\hline & TH4 & 29.8 & 5.2 & 65 & 14 & 0 & 15 & 4 & 1 & 0 & 0 & 0 & 0.97 \\
\hline \multicolumn{14}{|c|}{ Indonesia } \\
\hline & ID3 & 24.3 & 2.6 & 64 & 12 & 0 & 18 & 2 & 2 & 0 & 0 & 0 & 1.38 \\
\hline & ID5 & 30.9 & 6.2 & 63 & 15 & 0 & 15 & 0 & 1 & 0 & 0 & 6 & 1.07 \\
\hline & ID7 & 14.2 & 3.5 & 67 & 15 & 0 & 17 & 0 & 1 & 0 & 0 & 0 & 1.48 \\
\hline & ID9 & 16.9 & 2.2 & 76 & 13 & 0 & 10 & 0 & 1 & 0 & 0 & 0 & 1.59 \\
\hline & ID10 & 19.2 & 3.6 & 67 & 15 & 0 & 17 & 0 & 1 & 0 & 0 & 0 & 1.43 \\
\hline & ID12 & 6.3 & 2.2 & 75 & 5 & 2 & 15 & 2 & 1 & 0 & 0 & 0 & 1.76 \\
\hline & ID13 & 9.8 & 3.1 & 80 & 6 & 0 & 13 & 0 & 1 & 0 & 0 & 0 & 2.07 \\
\hline & ID14 & 9.8 & 2.7 & 72 & 12 & 0 & 14 & 1 & 1 & 0 & 0 & 0 & 1.63 \\
\hline & ID15 & 17.3 & 3.5 & 65 & 15 & 0 & 17 & 0 & 1 & 0 & 0 & 2 & 1.40 \\
\hline & ID17 & 11.5 & 2.5 & 76 & 9 & 0 & 13 & 1 & 1 & 0 & 0 & 0 & 1.63 \\
\hline & ID18 & 10.3 & 2.5 & 76 & 5 & 3 & 12 & 1 & 1 & 0 & 0 & 1 & 1.62 \\
\hline \multicolumn{14}{|l|}{ Japan } \\
\hline & JP1 & 17.0 & 4.6 & 60 & 15 & 1 & 18 & 2 & 1 & 0 & 0 & 4 & 1.36 \\
\hline & JP4 & 16.5 & 3.2 & 58 & 18 & 0 & 17 & 0 & 1 & 0 & 0 & 7 & 1.11 \\
\hline & JP6 & 28.4 & 5.9 & 65 & 15 & 0 & 14 & 0 & 1 & 0 & 0 & 5 & 0.87 \\
\hline & JP9 & 38.0 & 8.8 & 52 & 16 & 0 & 22 & 8 & 1 & 0 & 0 & 1 & 0.87 \\
\hline & JP11 & 21.3 & 5.0 & 58 & 20 & 0 & 20 & 0 & 2 & 0 & 0 & 0 & 1.16 \\
\hline & JP12 & 17.4 & 3.5 & 62 & 15 & 1 & 18 & 2 & 1 & 0 & 0 & 1 & 1.27 \\
\hline & JP13 & 49.6 & 9.6 & 45 & 12 & 5 & 33 & 2 & 1 & 0 & 0 & 2 & 0.87 \\
\hline & JP16 & 14.9 & 3.8 & 62 & 12 & 0 & 22 & 0 & 2 & 0 & 0 & 1 & 1.39 \\
\hline & JP17 & 36.5 & 7.2 & 53 & 17 & 2 & 22 & 3 & 1 & 0 & 0 & 1 & 0.88 \\
\hline & JP18 & 44.2 & 6.0 & 65 & 14 & 0 & 15 & 2 & 1 & 0 & 0 & 3 & 0.89 \\
\hline & JP19 & 12.0 & 2.8 & 57 & 15 & 0 & 20 & 0 & 1 & 0 & 0 & 6 & 1.09 \\
\hline \multicolumn{14}{|c|}{ Volcanic, Japan } \\
\hline & JP15 & 320 & 33.5 & 40 & 12 & 0 & 17 & 7 & 3 & 0 & 0 & 21 & 0.69 \\
\hline & JP20 & 176 & 22.1 & 45 & 17 & 3 & 31 & 2 & 2 & 0 & 0 & 0 & 0.83 \\
\hline & JP21 & 111 & 17.3 & 56 & 17 & 1 & 24 & 1 & 1 & 0 & 0 & 0 & 1.06 \\
\hline & JP22 & 109 & 17.5 & 54 & 14 & 0 & 14 & 8 & 1 & 0 & 0 & 8 & 0.89 \\
\hline
\end{tabular}

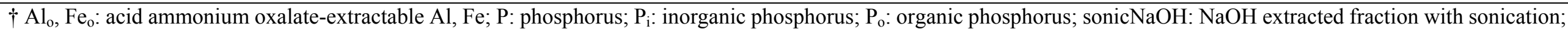
AEM: anion exchange membrane. 
Table 3. Specific surface area of total and micro- and meso-pores, and how much they decreased after phosphate sorption $\dagger$

\begin{tabular}{|c|c|c|c|c|c|c|c|}
\hline Region & Sample & $\begin{array}{l}\mathrm{Al}_{\mathrm{o}}+\mathrm{Fe}_{\mathrm{o}} \\
\mathrm{cmol} \mathrm{kg}{ }^{-1}\end{array}$ & $\begin{array}{l}\mathrm{SSA}_{\text {total }} \\
\mathrm{m}^{2} \mathrm{~g}^{-1}\end{array}$ & $\begin{array}{c}\mathrm{SSA}_{0.7-4 \mathrm{~nm}} \\
\mathrm{~m}^{2} \mathrm{~g}^{-1}\end{array}$ & $\begin{array}{c}\mathrm{SSA}_{0.7-4 \mathrm{~nm}} \\
/ \mathrm{SSA}_{\text {total }}\end{array}$ & $\begin{array}{c}\Delta \mathrm{SSA}_{\text {total }} \\
\mathrm{m}^{2} \mathrm{~g}^{-1}\end{array}$ & $\begin{array}{c}\Delta \mathrm{SSA}_{0.7-4 \mathrm{~nm}} \\
\mathrm{~m}^{2} \mathrm{~g}^{-1}\end{array}$ \\
\hline \multicolumn{8}{|l|}{ Thailand } \\
\hline & TH1 & 14.8 & 24.7 & $4.5 \dagger \dagger$ & 18.1 & 12.2 & 1.7 \\
\hline & TH2 & 9.5 & 23.7 & $4.4 \dagger$ & 18.5 & 1.6 & 0.3 \\
\hline & TH3 & 7.7 & 15.4 & $3.4 \dagger \dagger$ & 22.2 & 0.8 & 0.2 \\
\hline & TH4 & 29.8 & 38.2 & $7.1 \dagger \dagger$ & 18.7 & 5.4 & 0.7 \\
\hline \multicolumn{8}{|l|}{ Indonesia } \\
\hline & ID3 & 24.3 & 57.2 & 17.5 & 30.5 & 4.7 & 0.9 \\
\hline & ID5 & 30.9 & 53.6 & 30.9 & 57.6 & 27.5 & 24.9 \\
\hline & ID7 & 14.2 & 32.1 & $5.8 \dagger \dagger$ & 18.0 & 6.5 & 0.8 \\
\hline & ID9 & 16.9 & 19.9 & $3.5 \dagger$ & 17.7 & 2.6 & 0.2 \\
\hline & ID10 & 19.2 & 32.9 & $6.6+\dagger$ & 20.0 & 4.1 & 0.9 \\
\hline & ID12 & 6.3 & 28.2 & $5.4 \dagger \dagger$ & 19.1 & 2.9 & 0.4 \\
\hline & ID13 & 9.8 & 33.6 & $5.7 \dagger \dagger$ & 17.1 & 7.0 & 0.7 \\
\hline & ID14 & 9.8 & 18.6 & $3.7 \dagger$ & 19.9 & 2.3 & 0.4 \\
\hline & ID15 & 17.3 & 23.2 & $4.7 \dagger \dagger$ & 20.0 & 1.4 & 0.5 \\
\hline & ID17 & 11.5 & 23.1 & $4.4 \dagger \dagger$ & 19.1 & 5.2 & 0.4 \\
\hline & ID18 & 10.3 & 28.9 & $4.9 \dagger$ & 17.0 & 6.8 & 0.6 \\
\hline \multicolumn{8}{|l|}{ Japan } \\
\hline & JP1 & 17.0 & 32.7 & 13.2 & 40.5 & 9.3 & 9.0 \\
\hline & JP4 & 16.5 & 18.7 & $3.2 \dagger$ & 17.3 & 5.2 & 0.5 \\
\hline & JP6 & 28.4 & 45.4 & 14.7 & 32.3 & 9.6 & 8.1 \\
\hline & JP9 & 38.0 & 42.8 & 10.9 & 25.4 & 6.2 & 5.2 \\
\hline & JP11 & 21.3 & 51.2 & 23.6 & 46.1 & 8.3 & 10.0 \\
\hline & JP12 & 17.4 & 37.7 & 22.4 & 59.4 & 7.9 & 10.9 \\
\hline & JP13 & 49.6 & 32.8 & 19.7 & 60.2 & 4.6 & 5.0 \\
\hline & JP16 & 14.9 & 26.8 & $4.6+\dagger$ & 17.0 & 5.0 & 0.3 \\
\hline & JP17 & 36.5 & 33.9 & 9.3 & 27.4 & 4.7 & 4.4 \\
\hline & JP18 & 44.2 & 26.4 & 12.2 & 46.3 & 8.3 & 9.1 \\
\hline & JP19 & 12.0 & 26.6 & 6.2 & 23.3 & 4.7 & 2.0 \\
\hline \multicolumn{8}{|c|}{ Volcanic, Japan } \\
\hline & JP15 & 320 & 94.2 & 88.6 & 94.0 & 34.1 & 38.5 \\
\hline & JP20 & 176 & 60.6 & 48.7 & 80.5 & 5.1 & 8.2 \\
\hline & JP21 & 111 & 64.2 & 54.1 & 84.2 & 1.0 & 3.4 \\
\hline & JP22 & 109 & 73.5 & 63.6 & 86.5 & 18.4 & 19.1 \\
\hline
\end{tabular}

$\dagger \mathrm{Al}_{\mathrm{o}}, \mathrm{Fe}_{\mathrm{o}}$ : acid ammonium oxalate-extractable $\mathrm{Al}, \mathrm{Fe} ; \mathrm{SSA}_{\text {total }}$ : total specific surface area (SSA); $\mathrm{SSA}_{0.7-4 \mathrm{~nm}}$ : SSA of 0.7-4-nm pores; $\Delta \mathrm{SSA}_{\text {total }}, \Delta \mathrm{SSA}_{0.7-4 \mathrm{~nm}}$ : decrease in SSA of total and 0.7-4-nm pores after phosphate sorption treatment.

$\dagger \dagger$ Micropore $(<2 \mathrm{~nm})$ was not detected. 
Table 4. Spearman correlation coefficients $\uparrow$ between the value of extraction results and active $\mathrm{Al}$ and Fe contents and the porosity of the studied soils $\uparrow \dagger$

\begin{tabular}{|c|c|c|c|c|}
\hline & \multicolumn{3}{|c|}{ Hedley's fractionation } & \multirow{2}{*}{$\begin{array}{c}\text { Rate constant for } \\
\text { desorption with } \\
\text { AEM }\end{array}$} \\
\hline & $\begin{array}{c}\text { Resin } \\
-P\end{array}$ & $\begin{array}{c}\mathrm{NaHCO}_{3} \\
-\mathrm{P}_{\mathrm{i}} \\
\end{array}$ & $\begin{array}{c}\mathrm{NaOH} \\
-\mathrm{P}_{\mathrm{i}} \\
\end{array}$ & \\
\hline $\mathrm{Al}_{\mathrm{o}}+\mathrm{Fe}_{\mathrm{o}}$ & $-0.79 * * *$ & $0.55 * *$ & $0.55^{* *}$ & $-0.91 * * *$ \\
\hline $\mathrm{Al}_{\mathrm{o}}$ & $-0.81 * * *$ & $0.47 * *$ & $0.56 * *$ & $-0.90 * * *$ \\
\hline $\mathrm{Fe}_{\mathrm{o}}$ & $-0.44 *$ & $0.36^{*}$ & 0.23 & $-0.66 * * *$ \\
\hline $\begin{array}{c}\mathrm{SSA}_{0.7-4 \mathrm{~nm}} \\
/ \mathrm{SSA}_{\text {total }}\end{array}$ & $-0.72 * * *$ & $0.42 *$ & $0.46^{*}$ & $-0.70 * * *$ \\
\hline$\Delta \mathrm{SSA}_{0.7-4 \mathrm{~nm}}$ & $-0.68 * * *$ & $0.53 * *$ & $0.47 *$ & $-0.74 * * *$ \\
\hline
\end{tabular}

$\dagger * * *, * *, *$ : significant at probability levels of $0.001,0.01,0.05$,

respectively.

$\dagger$ † : phosphorus; $\mathrm{P}_{\mathrm{i}}$ : inorganic phosphorus; $\mathrm{P}_{\mathrm{o}}$ : organic phosphorus; $\mathrm{AEM}$ : anion exchange resin; $\mathrm{Al}_{\mathrm{o}}, \mathrm{Fe}_{\mathrm{o}}$ : acid ammonium oxalate-extractable $\mathrm{Al}, \mathrm{Fe}$; $\mathrm{SSA}_{\text {total }}$ : total specific surface area (SSA); $\mathrm{SSA}_{0.7-4 \mathrm{~nm}}$ : SSA of 0.7-4-nm pores; ${ }_{\mathrm{SSA}} \mathrm{SS}_{0.4 \mathrm{~nm}}$ : decrease in SSA of 0.7-4-nm pores after phosphate sorption treatment. 